\title{
金属性圧粒子の治験 例
}

\section{第 2 報：身体各部位に貼付した場合}

大阪医科大学麻醉学教室

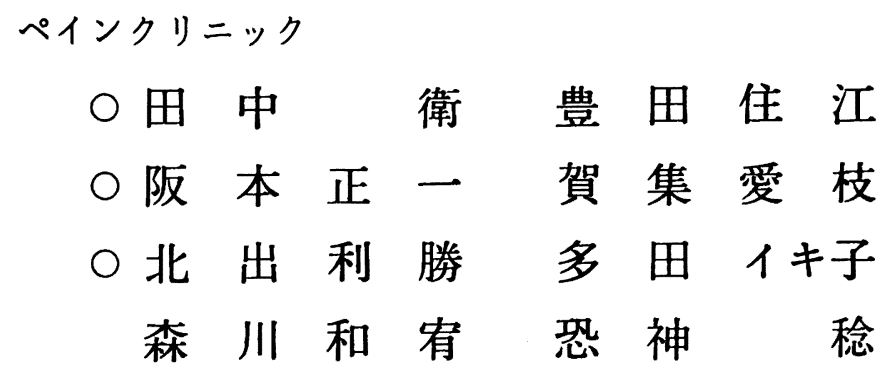

金属性圧粒子に対する压効果を試みるために われわれはまず「肩こり」を訴える患者に貼付 して、治療勃果を検討した。

これは、昭和 44 年 7 月中に当科外来を訪れた 30例に行われ、さらに同数の「有てり」症に同 し大きさを持った硝子粒子を対象として比較し た。てれにより、治療効果は四 1 の如く金属粒 子の方が効力持続において著明であり、また、 硝子粒子あ短時間ではあるが同様の勃力を示し すでに前回本誌溌表した。これらは、患者自 らの判断の下に圧痛の最大点に貼付したもので あった。乙れは昭和44年 8 月、厚生省提出資料 の結論であり、詳細はてれを参照されたい。こ れにより、患者の簡単な質問に答えることがで きる。

今回は、レントゲン所見等の異常を認められ ないものに直径 $1.2 \mathrm{~mm}$ の王粒子を用いて各種 部位に貼付し、他の治療法、内服、注射、理学 療法等を一切行わずに使用した。

施行者は、当科の医師、銊尒師である。 O圧柆子 直径 $1 \sim 1.5 \mathrm{~mm}$ のものであるが、 今回の治療に用いたものは直径 $1.2 \mathrm{~m} \mathrm{~m}$ で 1 粒 の重量 $0.0006 \mathrm{~g}$ の純鋼鉄製で、表面はニッケル メッキを与えたものを用い、硝子粒子と比較に

昭和44年 9 月 4 日（厚生省提出）

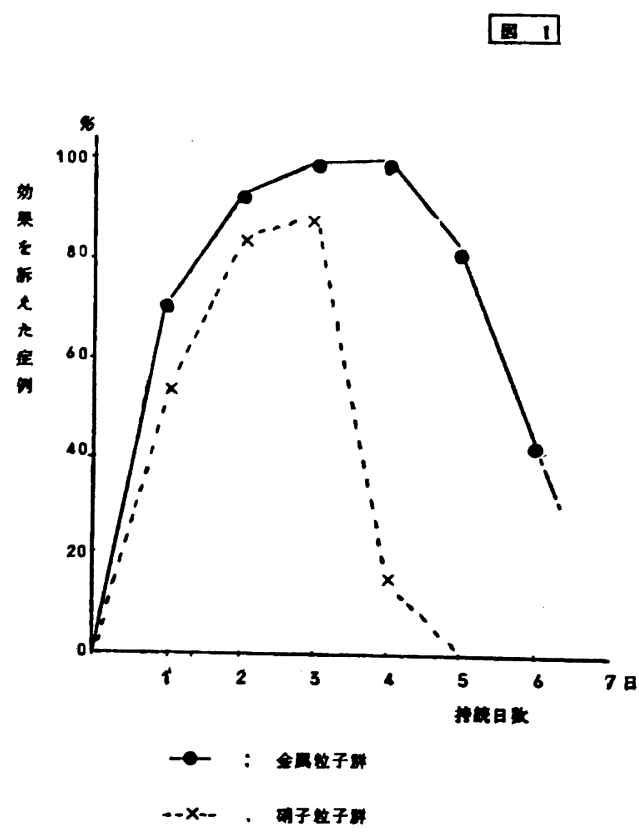

用いたものと同じ大きさのものである。

O貼付部位の決定 :

身体における深部組織の病的状態の反応が体 壁の表面に出現し、これが電流計の測定により 皮庙電気抵抗減弱部位、あるいは反応良導点、 または Galvanic Skin Reflex Point (GSR) として出現し、また、この部位における体表処 


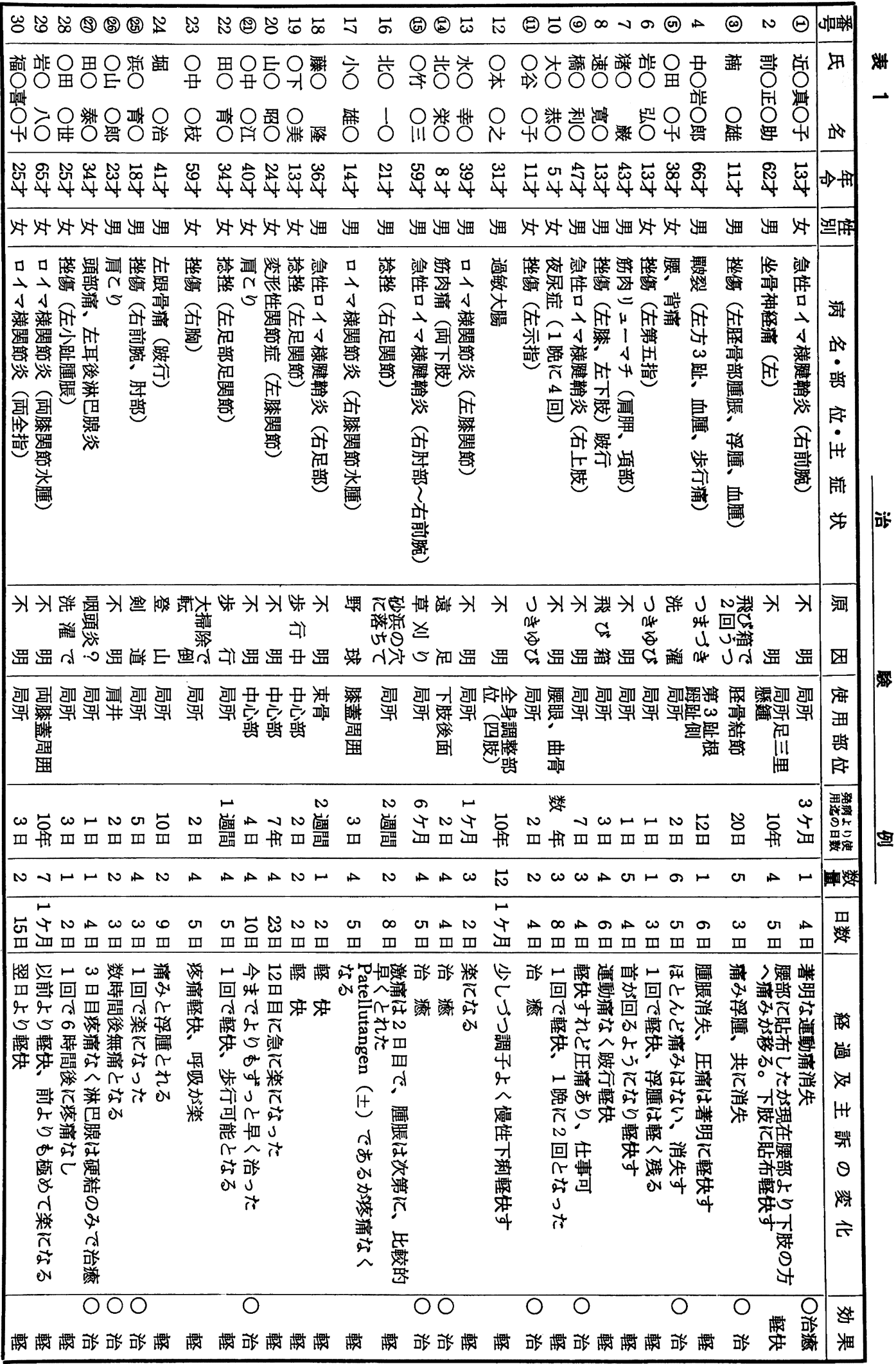


置が、深部器官に治療的に効果があるととろか ら、身体各部位の「いたみ」を訴えている部位 またはその部位を中心とした皮膚電気抵抗部位 を 1 数ヶ所選び貼付した。この部分は、必ず しあ圧痛点に一致するとは限っていない。

\section{○貼付部位の測定 :}

器械は、笹川・中谷によるノイロメーター （ノイロ医科工業KK製）を使用し、12V $200 \mu$ AK Ajust し湿性の陰極を用い測定し、 $75 \mu \mathrm{A}$ 以上を示す部位を貼付部位と定めた。

O症例 : 表 1

表 1 に示すように、各種の突患でそれぞれ各 部位に疼痛を有し、その局所は湿布処置、理学 療法等が適当であろうといえるものであった。 これらのものは、昭和43年10月より昭和44年 3 月迄に当科へ来院し、注射、内服、他の理学療 法を行なっていないあの 100 例で、1.0〜 $1.5 \mathrm{~m}$ $\mathrm{m}$ の金属性圧粒子（点療球）の内、 $1.2 \mathrm{~mm}$ を 使用したすの30例である。

すなわち、原病といえるすのは次の如く、 1）挫傷 9 例、2) 筋肉痛（腰、背、肩およびそ の他） 5 例、3）腱鞘炎 4例、4） ロイマ様関節 炎 4 例、5）捻挫 2 例、6） その他各 1 例（坐骨 神経痛、変形性関節症、跟骨痛、急性耳后归 八腺炎、夜尿症、過敏大腸）である。乙の内、 過敏大腸、夜尿症には東洋医学的経空を使用し た。

\section{○性 別:}

男 17例、女 13例

\section{○年令展 :}

男 5 才 50才、女11才〜 65才である。

\section{○効果判定: 図 2 表 1}

効果判定は、圧粒子による除痛効果を目標に 行ない、来院毎の自覚症状により判定した。表 1 の番号丸印は治瘾したものを示しており、治 瘾11例、軽快19例であり、無効、悪化例はなか った。

\section{O貼付局所（有痛部位）の状秘：}

王痛と共存していた硬結、皮下出血、血腫ま たは着色部む徐々に圧粒子を中心として消褪し ていった。

その他、圧粒子そのあのによる圧迫痕は「肩 こり」に用いた時（前回発表）と同様。直径約
$1 \mathrm{~mm}$ の陷凹となって残存し、絆創亭による皮 噟炎以外の所見は認められず、重篤な副作用も 認められなかった。
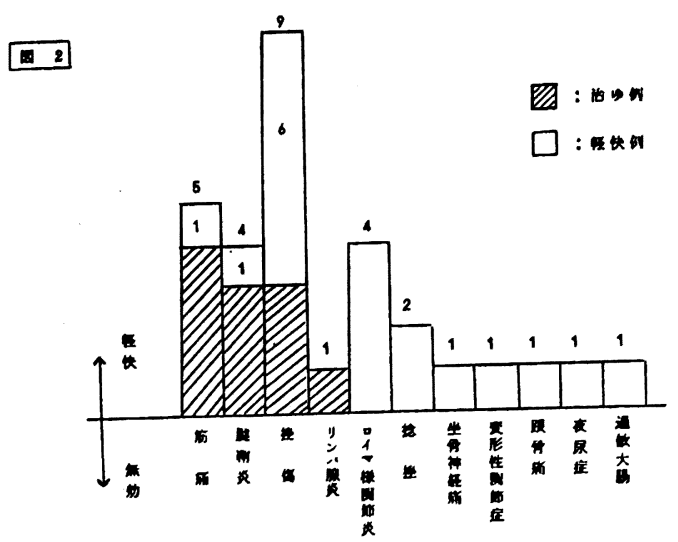

\section{○除痛または軽快・治瘾迄の期間 : 表 2}

圧粒子の作用は同一部における同じ圧力が、 時間的に加重される効果として考えると、軽快 または治瘾例はともに第 3、4、5 日目の間に 最大効力を示し、治瘾したものが集中して見ら れる。頻回の貼付による部位の移動は判定を煩 雑化するため、初回貼付部位にさらに貼付して 行なった。

\begin{tabular}{|c|c|c|}
\hline \multicolumn{3}{|c|}{ 除痛或は治療又は軽快迄 } \\
\hline 1 日 & 0 & 人 \\
\hline 2 & 4 & \\
\hline 3 & 4 & (3) \\
\hline 4 & 6 & $(5)$ \\
\hline 5 & 6 & (2) \\
\hline 6 & 2 & \\
\hline 8 & 2 & \\
\hline 9 & 1 & \\
\hline 10 & (1) & \\
\hline 15 & 1 & \\
\hline 23 & 1 & \\
\hline 30 & 2 & \\
\hline
\end{tabular}

\section{O使用個数 :}

部位、範囲により異なることは当然であるが 全使用個数 102 ケ、 1 人平均 3.4 個であった。

\section{○考 按 :}

金属粒子を身体各部位の圧痛点または「つ ほ」に貼付し、これによる治療効果を期待する 
のは、ヨーロッパにおいては数世紀前より行わ れていた。わが国においては、佐藤三郎、間中 喜雄、中谷義雄等により、10年以前より試みら れている。

(1) 金属粒子を体壁に使用する場合、王粒子の 貼付部位が皮佣電気抵抗減弱部位として残る この時間的な測定は、著者の一人北出利勝に より、第15回日本鍼炎学会において、「反応 良導点 (R.E.P.P.) 探索の支障となる諸 因子について」として報告された。われわれ はこの実験を行なうにあたり、これら阻害因 子を除去するため、初回測定の部位を最後迄 用いた。

(2) 硝子粒子と金属粒子の肩てりに対する効果 の比較は、著者等によって行われたが、金属 粒子の方が硝子粒子よりあ効果の持続面で、 頻回の貼付を要せず持続していた。

これは、金属自身の皮有接触作用によるも のか、暗示勃果によるあのかは不明であり、 なお、検討を要することである。

(3) 効果判定面では、治瘜または除痛および軽 快と分けて観察したところ、無効例なく、11 例に除痛または治瘾、19例に柽快を見た。除 痛勃果は、3、4、5 日目が最高であった。

(4) 効力の出現は、極めて弱い圧迫刺戟が時間 的に加重され、有効刺戟となった時除痛効果 を見るのであり、今回のように電流計による 皮唐電気抵抗減弱部位に作用させても、副作 用なく除痛効果を示した。図 3

これは「いたみ」の治瘾の一方法、補助方 法、湿布処置の代用等としても有効であると 思われる。

(5) レントゲン撮影時、圧粒子を貼付するとと により、患者の有痛部位との関係が明瞭とな り説明に便利である。

\section{○結 語}

1）一般に種々行われている治療法の内、金属 粒子使用の効果について系統的な報告は少な い。

前回発表分と同様に、直径 $1.2 \mathrm{~mm}$ の金属 性圧粒子を用い、身体各部位における「いた み」に対する除痛効果を検討した。

2）貼付部位として、ノイロメーター（ノイロ
医科工業製）による測定による、皮府電気抵 抗減弱部位に 1 数個宛使用し、剝脱した場 合も同一部位に貼付し測定時の阻害因子を除 去した。

3）貼付結果として、軽快19例、治瘾11例、無 効なしという結果を得、約 $36 \%$ に治療を認め た。図 3

副作用として重篤なものなく、極めて安全 であるととを示した。

4）レントゲン撮影時に、貼付するときの目標 となり便利である。

今回の実験は予備実験的なるのであったが 種々な疾患に生ずる身体各部位の「いたみ」 に対して、金属性圧粒子の貼付は鎮痛的に作 用することを確認し、また、とれら症状にお ける補助療法、すなわち、指圧、湿布処置あ るいは理学的療法の代用として有効であると 認めた。

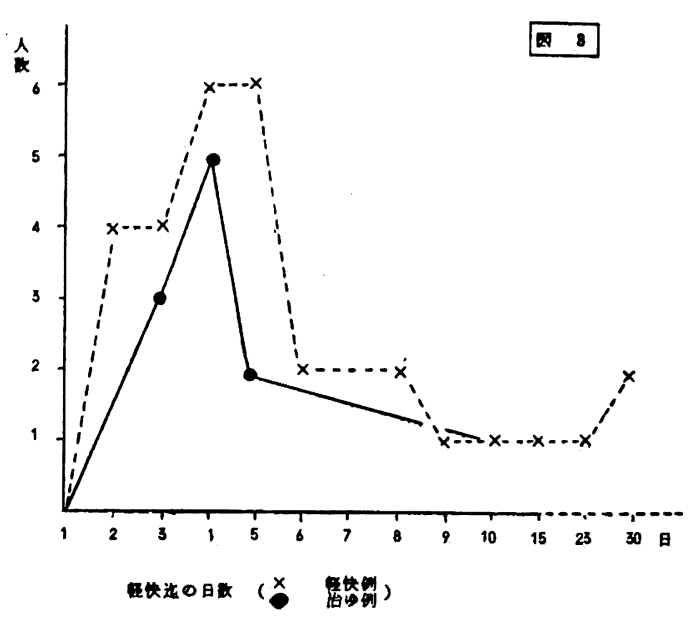

参考文献・図西

1）間中喜雄、ヘリベルト・シュミット共著 鍼術入門講座、医道の日本社 42.8 .15

2）間中喜雄 肩とりと腰痛、創元社 43.8.1

3）田中衛他 肩とりに対する圧粒子療法の効 果について 44.8 .9

4）東京教育大・理療科研究室 理療科教育研究抄録 昭35-43年

5）北出利勝 第15回日本鍼尒学会発表 昭44 「反応良導点探索の支障となる諸因子につ いて」

(終り) 